\title{
Incorporating resistance to Xanthomonas campestris pv. phaseoli into bean using the latent period as a resistance marker ${ }^{1,2}$
}

\author{
Mildred Zapata, Robert Wilkinson, George F. Freytag ${ }^{s}$, Hiram Vélez ${ }^{6}$ \\ Francisco H. Ortiz ${ }^{7}$, and Julio H. López-Rosa ${ }^{8}$
}

\begin{abstract}
High levels of resistance to Xanthomonas campestris pv. phaseali (Xcp) were developed in the common bean (Phaseolus vulgaris L.) by intercrossing genotypes having moderate levels of resistance. This was accomplished by using a modified backcross method. Screening for resistance was based on the length of the latent period for seedlings inoculated in the primary leaves, via the multineedle wounding method, and incubated in a $29^{\circ} \mathrm{C}$ controlled growth chamber. Field and greenhouse screening was conducted under tropical conditions with $X_{c p}$ strains from Puerto Rico. Selected lines were incorporated into the crossing program. Homozygosis of the best lines was increased through greenhouse and field planting for six summer seasons. Resistance was reconfirmed by inoculation of the lines with $X$. campestris pv. phaseoli, vignicola and glycines under controlled conditions. Three determinate and two indeterminate germplasm lines in the $F_{B}$ generation, resistant to bacterial blight, were released as an outcome of this research.
\end{abstract}

\section{RESUMEN}

Incorporación de resistencia a Xanthomonas campestris pv. phaseoli a la habichuela con la latencia como marcador de resistencia

Se desarrollaron niveles de alta resistencia a Xanthomonas campestris pv. phaseoli $\left(X_{c p}\right)$ mediante intercruzamiento y retrocruzamiento de seis genotipos de habichuela (Phaseolus vulgaris L.) con alguna resistencia al tizón común. La selección de resistencia se basó en el largo del período de incubación de plántulas inoculadas con $X_{c p}$ en las hojas primarias mediante el método de agujas múltiples e incubación en una cámara de ambiente controlado a $29^{\circ} \mathrm{C}$. Se seleccionaron líneas de alta resistencia en pruebas de invernadero y de campo bajo condiciones tropicales. Las

'Manuscript submitted to Editorial Board 6 March 1990.

2This study was conducted under UPR-Project CBAG-18, Production of bacterial blight (Xanthomonas spp.) resistance bush bean germplasm. It has been supported in part by grants from the Agency for International Development (AID/CM/TA-C73-26, AID/TA-C1296, AID/DSAN/XII-G-0261) and the NY State Dry Bean Growers and Shippers fund.

${ }^{3}$ Associate Phytopathologist, Department of Crop Protection.

'Professor Emeritus, Department of Plant Pathology, Cornell University, Ithaca, New York.

${ }^{6}$ Research Geneticist, USDA/Tropical Agriculture Research Station, Mayagüez, P, R.

-Research Assistant, Department of Crop Protection.

'Assistant Agronomist (retired), Department of Horticulture.

aphytopathologist (Ad Honorem), Department of Crop Protection. 


\begin{abstract}
líneas seleccionadas se incorporaron a un programa de cruzamiento y las mejores se purificaron en condiciones de invernadero y de campo. La resistencia se reconfirmó mediante la inoculación de $X$. campestris pv. phaseoli, vignicola y glycines bajo condiciones controladas. Como resultado de este estudio se liberaron oficialmente cinco líneas de germoplasma (tres de tipo determinado o arbustivo y dos de tipo indeterminado o de guía) en la generación $F_{8}$ resistentes al tizón bacteriano.
\end{abstract}

INTRODUCTION

Few commercial bean (Phaseolus vulgaris L.) cultivars are resistant to common bacterial blight caused by Xanthomonas campestris pv. phaseoli $=$ X. phaseoli $($ E. F. Sm.) Dow. Nebraska Great Northern No. 1, Sel. 27, has been used as a standard and is recognized as having a useful level of resistance to the pathogen. However, the common bacterial blight resistance of Sel. 27 and GN 1 is not as great at that found in some tepary beans $(P$. acutifolius Gray) $(3,5,6,10,11)$. It is necessary to continue identifying and utilizing additional sources of resistance to develop new bean cultivars. This need is underlined by the genetic vulnerability to common blight in both dry and snap beans, as reported by the Committee on Genetic Vulnerability of Major Crops of the National Research Council (1).

Resistance to common blight is multigenic in Phaseolus vulgaris (2, 12). Determinate (bush) types are normally very susceptible to the bacterium. In contrast, good levels of resistance have been found in lines with indeterminate (vine) growth habit from Cornell University and elsewhere. This research explores how to combine different sources of bacterial blight resistance and to incorporate this resistance into a determinate plant type.

\title{
MATERIALS AND METHODS
}

\section{Breeding}

Sources of resistance (GN-1, Sel. 27, introductions 207262, 180745, 180746 and 65859) were intercrossed by a modified backcross method to pyramid genes for resistance to common blight (table 1).

The reciprocal backcross process of pyramiding genes for resistance began with crossing two plants that derive resistance from two different sources. After two generations of screening the progeny of the cross, the hybrid was backcrossed to each parent. Again, the progeny from the two backcrosses was screened for resistance for two generations. The plants with the best resistance in each backcross population were intercrossed. The progeny from the reciprocal backcrosses was assumed to carry most of the genes for resistance from each original source.

The transfer of greater levels of resistance into determinate material involved the backcross of the (determinate $\times$ indeterminate) $F_{1}$ to a similar high level resistant vine. The $\mathrm{F}_{2}$ populations of the [(determinate 
TABLE 1.-Sources of resistance to Xcp that entered into the background of the individual bean (Phaseolus vulgaris) lines

\begin{tabular}{lcccccc}
\hline & \multicolumn{7}{c}{ Source of resistance } \\
\cline { 2 - 7 } Line \\
identity & GN-1 & Sel. 27 & 207262 & 180745 & 180746 & 65859 \\
\hline W-BB-20-1 & $\mathrm{X}^{2}$ & $\mathrm{X}$ & $\mathrm{X}$ & $\mathrm{X}$ & $\mathrm{X}$ & $\mathrm{X}$ \\
W-BB-35 & $\mathrm{X}$ & $\mathrm{X}$ & $\mathrm{X}$ & $\mathrm{X}$ & $\mathrm{X}$ & $\mathrm{X}$ \\
W-BB-52 & $\mathrm{X}$ & $\mathrm{X}$ & $\mathrm{X}$ & $\mathrm{X}$ & & $\mathrm{X}$ \\
W-BB-11 & $\mathrm{X}$ & $\mathrm{X}$ & $\mathrm{X}$ & $\mathrm{X}$ & $\mathrm{X}$ & \\
W-BB-II-56 & $\mathrm{X}$ & $\mathrm{X}$ & $\mathrm{X}$ & & & $\mathrm{X}$ \\
\hline
\end{tabular}

'Source of resistance GN-1 = Univ. of ldaho Great Northern \#1. Sel. 27 = Great Northern Nebraska \#1 Selection 27; 207262 = Plant Introduction 207262 from Columbia, SA; 180745, $180756=$ Plant Introduction ( $P$. coccineus $\times P$. vulgaris) from Germany; $65859=(P$. vulgaris $\times P$, coccineus) from $P$. A. Lorz, Univ, of Florida.

Indication of the germplasm contributor to each line.

$\mathrm{x}$ indeterminate) $\times$ indeterminate] backcrossed were grown at Isabela. Seed of bush segregates were harvested and screened for resistance in a growth chamber in Ithaca, New York, and in the field in Juana Díaz, Puerto Rico. The (determinate $\times$ indeterminate) $F_{2}$ plants were backcrossed to the selected breeding lines (parents) containing high levels of resistance.

\section{Screening}

Resistance to common blight was determined by screening promising families for their latent period (length of time between inoculation and symptom expression). Indicator plants used in each experiment were Redkote (susceptible) and Sel. 27 (resistant). Inoculation by the multineedle technique (9) was conducted on primary leaves of 8-day-old seedlings with $10^{8} \mathrm{CFU}$ in a controlled growth chamber at about $85^{\circ} \mathrm{F}\left(29^{\circ}\right.$ C). Symptom development was observed daily. Resistant plants which showed a hypersensitive reaction at $24-48 \mathrm{~h}$ were discarded. Susceptible plants showing water-soaking, chlorosis, or progressive necrosis were discarded as soon as detected. Only plants showing no symptoms or having a longer incubation time than Sel. 27 were maintained.

The tests for resistance in the growth chamber consisted of three benches holding 28 rows of 7 three-inch pots. One to three seeds were planted in each three-inch pot. Each bench included a susceptible and a resistant check. One row (7 pots) of each entry was planted. Two seeds per pot were planted for early generation material. $\mathrm{F}_{2}$ seeds were planted densely in two rows making 28 seeds per $\mathrm{F}_{2}$ population.

It was possible to follow a planting schedule of one bench (about 28 entries) each week. However, when material took 14 or more days to develop symptoms, replanting of the bench was delayed. Generally, the 
material used to plant one bench in the growth chamber consisted of one or more related groups or families. When $\mathrm{F}_{2}$ populations were screened, one or both parents were included, especially when no obvious phenotypic markers were present to help confirm hybridity. Comparisons with parents also provided a measure of the effect of pyramiding genes for resistance. Plants saved from screening tests were transplanted to larger pots in the greenhouse and held for seed production and possible future crossing.

Individual lines were tested for resistance under greenhouse and field conditions. In the greenhouse they were tested with Xcp strains from Puerto Rico and the American Type Culture Collections (ATCC) (Xc pv vignicola and Xc pv glycines). Also, they were tested in the field with other Xcp field strains.

Field tests were conducted in Fortuna and Isabela, Puerto Rico. In these tests, fifty seeds of each selection were planted and inoculated near the flowering stage. The scale for evaluation of the disease on foliage ranged from 1-5 $(1=$ resistant, $2=$ slightly susceptible (slow disease development with very small chlorotic lesions, and little necrosis), $3=$ moderately susceptible, (necrosis on $1 / 4$ of the tissue affected), $4=$ susceptible (50\% of the tissue is necrotic) and $5=$ highly susceptible $(100 \%$ of the leaf tissue affected).

The scale of response to bacterial blight on pods under field conditions ranged from 1-3 $[1=$ resistant, $2=$ susceptible, (small water-soaked lesions)] and $3=$ highly susceptible (water-soaked lesions, necrotic tissue and/or sutures infected).

The $\mathrm{F}_{3}$ and $\mathrm{F}_{4}$ generations from the most resistant selections at Cornell were planted in the field and greenhouse in Puerto Rico for continued screening and selection. A bacterial blight screening plot was planted at the Fortuna Substation in August 1983. Approximately 21 selections were made from this planting under high bacterial blight stress, which was increased by artificial field inoculation. Three determinate lines (R$100 \mathrm{~b}, 116 \mathrm{~b}$ and $196 \mathrm{~b}$ ) showing resistance were identified. These were intercrossed along with other germplasm sources resistant to bacterial strains from New York. Lines showing higher resistance than Sel. 27 were selected as parents for the breeding program if the pedigree suggested that it contained unique resistance genes and would increase genetic diversity.

By the end of June 1984, a total of 1,278 entries had been screened in 45 high temperature growth chamber tests at Ithaca. One hundred and three $\mathrm{F}_{4}$ and $\mathrm{F}_{5}$ breeding lines and $79 \mathrm{~F}_{2}$ populations selected from these tests were planted at Fortuna in 1984 for screening for bacterial blight resistance under field conditions. The most resistant selections from the 1984 trial were crossed with determinate plant types, and the bush segregates with this pyramided resistance were selected in the field 
at Isabela. The $\mathrm{F}_{5}$ generation seeds from determinate plants were divided into two parts. One part was greenhouse-tested in Puerto Rico during the summer of 1985, and the other part was screened in environmental chambers at Ithaca. By the end of October 1985, about 3,000 entries had been screened in 108 growth chamber tests. This scheme utilized at least one virulent bacterial strain from Puerto Rico and one from New York. The bacterial blight resistant determinate lines were subjected to 4 more years of continued disease pressure in the field in Puerto Rico, and the best lines were selected to obtain homozygous breeding lines for release ( $F_{8}$ generation).

Resistant plants were grown in nurseries during the winter seasons at the TARS Isabela Farm and selected for plant habit and yield potential. Foliage resistance on individual plants at flowering was confirmed three times via multi-needle inoculation in the greenhouse using $X$. campestris pathovars phaseoli, vignicola and glycines from the ATCC and Pueto Rico collection. In addition, they were artificially inoculated under field conditions in Juana Díaz,. P. R., during the summer seasons.

\section{RESULTS}

The incorporation of resistance to bacterial blight into the determinate type was successfully attained in lines W-BB-20-1, W-BB-35 and W-BB-52 (table 2). Lines W-BB-11 and W-BB-56 are indeterminate (short vine) plants.

Lines were first improved by incorporating resistance into indeterminate (semivine and vine) types. This resistance was tested and confirmed

TABLE 2.-Reaction of determinate and indeterminate lines to inoculation with different bacterial strains'

\begin{tabular}{|c|c|c|c|c|c|c|}
\hline \multirow[b]{2}{*}{ Identity ${ }^{2}$} & \multicolumn{3}{|c|}{$\begin{array}{l}\text { Greenhouse } \\
\text { pv/origin }^{3}\end{array}$} & \multirow[b]{2}{*}{$\begin{array}{l}\text { vignicola } \\
\text { ATCC }\end{array}$} & \multirow[b]{2}{*}{$\begin{array}{l}\text { glycines } \\
\text { ATCC }\end{array}$} & \multirow{2}{*}{$\begin{array}{c}\text { Field } \\
\begin{array}{c}P R \\
\text { field }\end{array}\end{array}$} \\
\hline & ATCC & $\begin{array}{c}\text { phaseoli } \\
\text { PR }\end{array}$ & (F)ATCC & & & \\
\hline W-BB-20-1 & $1^{4}$ & 1 & 1 & 1 & 1 & 1.5 \\
\hline W-BB-35 & 1 & 1 & 4 & 1 & 1 & 2 \\
\hline W-BB-52 & 1 & 1 & 1.5 & 1 & 1 & 4 \\
\hline W-BB-11 & 1 & 1 & 2 & 1 & 1 & 2 \\
\hline W-BB-I1-56 & 1 & 1 & 1 & 1 & 1 & 1.5 \\
\hline
\end{tabular}

'Bacterial strains used comprised Xanthomonas campestris pathovars phaseoli, vignicola and glycines; and phaseoli (fuscans) $=\mathrm{f}$.

'Identity: Lines W-BB-20-1, W-BB-35 and W-BB-52 have a determinate plant habit. Lines W-BB-11 and W-BB-II-56 have an indeterminate (short vine) plant habit.

'Bacterial strain origin: $A T C C=$ American Type Culture Collection, $P R=$ Univ. of Puerto Rico and Tropical Agriculture Research Station Collection, field = strains collected at Juana Diaz, Puerto Rico.

${ }^{4}$ Reaction: 1 = Resistance, 1.5 = Slightly susceptible or (very slow disease development), 2 = Slightly susceptible (slow disease development), $4=$ Susceptible. 
in the breeding lines for at least 4 generations. The evaluation of the selected population from Fortuna in 1983 indicated that $30 \%$ had the same resistance level as Sel. 27, and $24 \%$ expressed greater resistance than Sel. 27. The 1984 planting showed marked improvement in bacterial blight resistance and in number and determinate entries over the 1983 plot. These lines were slightly susceptible to the disease under environmental chamber, field and greenhouse conditions.

Under controlled conditions, the susceptible Redkote developed symptoms in 4 days, and Sel. 27, the resistant indicator, developed symptoms in about 7 days. Latent periods as long as 10 days were recorded for some lines during the first year. A few plants were selected which had a latent period of 14 days during the second year. By 1985, a 14-day latent period was not uncommon and several plants with an 18-day latent period were selected. The selected lines showed no symptoms or were very slightly susceptible to most of the Xcp strains. Exceptions were line W-BB-35, which showed susceptibility to the fuscans strain, and W-BB-52, which was susceptible to the field Xcp strains but not to the others (table 2). All lines were resistant to pv. vignicola and glycines.

In order to characterize the magnitude of the improvement of the $\mathrm{F}_{4}$ and $F_{5}$ populations tested in 1984 , data were summarized by using Sel. 27 (best source of resistance known in $P$. vulgaris) and Redkote (susceptible) as standards of reference. During the first 14 days after inoculation, $31 \%$ of the population showed the same level of resistance as Sel. 27 (table 3). At 34 and 44 days after inoculation $42-54 \%$ of the population had higher foliage resistance than Sel. 27 (table 3). However, Sel. 27 showed resistance in the pods throughout the period of observation (table 4). Ninety-seven lines showed a pod tissue resistant response similar to that of Sel. 27 forty-four days after inoculation. It was observed that plants showing foliage resistance were not necessarily pod resistant and vice versa. In this regard, the most important achievement with the new lines was an improvement in foliage resistance.

TABLE 3.-Population comparison according to bean foliage response to field inoculation with Xanthomonas spp. ion 1984 at Fortuna, Puerto Rico

\begin{tabular}{|c|c|c|c|c|c|c|c|c|c|}
\hline \multirow[b]{3}{*}{$\begin{array}{l}\text { Days after } \\
\text { inoculation }\end{array}$} & & & \multicolumn{6}{|c|}{ Population Percentage } & \multirow[b]{3}{*}{$\begin{array}{l}\text { No. of } \\
\text { lines }\end{array}$} \\
\hline & \multicolumn{2}{|c|}{ Foliage ' } & \multicolumn{2}{|c|}{ Better than } & \multicolumn{2}{|c|}{ Same as } & \multicolumn{2}{|c|}{ Worse than } & \\
\hline & $\begin{array}{l}\text { Sel. } \\
27\end{array}$ & $\begin{array}{l}\text { Red } \\
\text { Kote }\end{array}$ & $\begin{array}{c}\text { Sel. } \\
27\end{array}$ & $\begin{array}{l}\text { Red } \\
\text { Kote }\end{array}$ & $\begin{array}{l}\text { Sel. } \\
27\end{array}$ & $\begin{array}{l}\text { Red } \\
\text { Kote }\end{array}$ & $\begin{array}{c}\overline{S e l}, \\
27\end{array}$ & $\begin{array}{l}\text { Red } \\
\text { Kote }\end{array}$ & \\
\hline 14 & 1 & 2 & 0 & 41 & 31 & 32 & 69 & 27 & 260 \\
\hline 34 & 2 & 3 & 42 & 73 & 13 & 14 & 45 & 14 & 260 \\
\hline 44 & 3 & 4 & 54 & 82 & 7 & 17 & 39 & 1 & 257 \\
\hline
\end{tabular}

'Scale of response to bacterial blight ranges from 1 = resistant, 2 = slightly susceptible, $3=$ moderately susceptible; $4=$ susceptible and $5=$ highly susceptible. 
TABLE 4.--Population comparison according to bean pod tissue response to field inoculation with Xanthomonas spp. in 1984 at Fortuna, Puerto Rico

\begin{tabular}{|c|c|c|c|c|c|c|c|c|c|}
\hline \multirow[b]{3}{*}{$\begin{array}{l}\text { Days after } \\
\text { inoculation }\end{array}$} & & & \multicolumn{6}{|c|}{ Population (No. of lines) } & \multirow{3}{*}{$\begin{array}{l}\text { Total } \\
\text { No. of } \\
\text { lines }\end{array}$} \\
\hline & \multicolumn{2}{|c|}{ Pod: } & \multicolumn{2}{|c|}{ Better than } & \multicolumn{2}{|c|}{ Same as } & \multicolumn{2}{|c|}{ Worse than } & \\
\hline & $\begin{array}{l}\text { Sel. } \\
27\end{array}$ & $\begin{array}{l}\text { Red } \\
\text { Kote }\end{array}$ & $\begin{array}{l}\text { Sel. } \\
27\end{array}$ & $\begin{array}{l}\text { Red } \\
\text { Kote }\end{array}$ & $\begin{array}{l}\text { Sel. } \\
27\end{array}$ & $\begin{array}{l}\text { Red } \\
\text { Kote }\end{array}$ & $\begin{array}{l}\text { Sel. } \\
27\end{array}$ & $\begin{array}{l}\text { Red } \\
\text { Kote }\end{array}$ & \\
\hline 34 & 1 & 1 & 0 & 0 & 215 & 215 & 45 & 45 & 260 \\
\hline 44 & 1 & 2 & 0 & 152 & 97 & 38 & 152 & 59 & 249 \\
\hline
\end{tabular}

'Scale of response to bacterial blight ranged from $1=$ resistant, $2=$ susceptible, $3=$ highly susceptible.

\section{DISCUSSION}

Bean cultivars generally depend upon a relatively narrow germplasm base, and the multi-strain resistance of $P$. vulgaris to Xcp seems to be controlled by minor genes which apparently act in an additive manner. The results show that the use of different sources of resistance, selected in both Puerto Rico and New York, combined with a screening procedure based on the length of the incubation period as a resistance marker increases the level of common blight resistance in determinate and indeterminate breeding lines. These improvements have been achieved by transferring resistance from indeterminate common beans to determinate beans. Using a screening procedure based on the length of the latent period, we achieved a selection against the hypersensitive resistant reaction which has been related to major genes. Most important, bacterial blight resistance is now available in plants of the determinate growth habit, which have been more susceptible than indeterminate beans. The bacterial blight resistant determinate lines are now available as homozygous breeding lines and as such have been released (7).

A high degree of recessiveness in the genes for resistance to Xcp from many sources has been observed (Wilkinson, unpublished). Thus, heterozygous loci do not contribute to resistance. The modified backcross procedure used in this study has the advantage of producing a higher percentage of homozygosity in which the recessive genes for resistance from both parents as well as some minor genes can be expressed. Results show that the modified backeross selection procedure is essential to accomplish satisfactory pyramiding of genes for resistance.

High level of resistance originated from $P$ haseolus coccineus has been reported in lines XR-235-1-1 $(4,8)$. Inheritance of resistance in $P$. acutifolius is due to dominant genes $(3,5)$. Resistance from $P$. acutifolius, which was inherited simply, has been transferred to lines Xan 159 and Xan 160 (6). Unfortunately, this source of resistance has already proven to be susceptible to certain Xcp strains from the Domini- 
can Republic. This fact emphasizes the need for durable resistance as evolved from this study. A combination of specific resistance in the Xan or tepary lines (dominant genes) with the resistance of our lines (assuming that all genes for resistance in these lines are recessive) should greatly reduce the chances for a virulent strain to arise. The explanation is that pathogens seem less likely to adapt and become virulent in plants that carry multigenic resistance. Single gene resistance frequently proves to be unstable and to "break down" because the bacterium is able to adapt and become virulent in plants that carry only a single gene for resistance. However, single gene resistance may be enhanced when combined with multigenic resistance.

\section{LITERATURE CITED}

1. Committee on genetic vulnerability of major crops, 1972. Dry beans. National Acad. Sci., Washington, D. C.

2. Coyne, D. P. and M. L. Schuster, 1974. Breeding and genetic studies of tolerance to several bean (Phaseolus vulgaris L.) bacterial pathogens. Euphytica 23: 651-56.

3. Drifhout, E., 1987. Inheritance of resistance to common bacterial blight in tepary bean. Bean Improvement Cooperative Report 30: 57 .

4. Freytag, G. F., M. J. Bassett and M. Zapata, 1982. Registration of XR-235-1-1 Bean Germplasm (Reg. No. GP 42). Crop Sci, 22: 1168-69.

5. Freytag, G. F., 1989. Inheritance of resistance to three strains of common bacterial blight (Xanthomonas campestris) in the cultivated tepary bean (Phaseolus acutifolius var latifolius). Bean Improvement Cooperative Report 32: 101.

6. McElroy, J. B., 1985. Breeding dry beans Phaseolus vulgaris L. for common bacterial blight resistance derived from Phaseolus acutifolius A. Gray. Ph.D. Thesis Cornell Univ.

7. U.S. Dept. of Agric., Cornell Univ. and Agric. Exp. Stn. Univ. P. R. 1990. Release of five common bean germplasm lines resistant to bacterial blight (Xanthomonas campestris pv. phaseoli).

8. U.S. Dept. of Agric., Agric. Exp. Stn. Univ. P. R. and Institute of Food and Agricultural Sciences Univ. Florida. 1981. Release of bacterial blight (Xanthomonas spp.) resistant XR-235-1-1 bean germplasm.

9. Zapata, M., G. F. Freytag and R. E. Wilkinson, 1985. Evaluation for bacterial blight resistance in beans. Phytopathology 75: 1032-39.

10. — and A. K. Vidaver, 1987. Differentiation of Xanthomonas campestris pv. phaseoli into pathogenic races based on Tepary bean reactions, Phytopalhology 77: 1709.

11. — 1989. Host-pathogen interactions of the tepary bean, Phaseolus acutifolius, with the common bean blight pathogen, Xanthomonas campestris pv. phaseoli. Ph.D. Thesis. Nebraska Univ.

12. Zaumeyer, W. J. and J. P. Meiners, 1975. Disease resistance in beans. Annu. Rev. Phytopathol. 13: 313-34. 